\title{
EVALUATION OF CLEAN WATER SUPPLY SYSTEMS OF DARUL HIKMAH MOSQUE IN POLITEKNIK NEGERI SEMARANG
}

\author{
Stefanus Santosa $^{1)}$, Edy Suhartono ${ }^{1, *)}$, Lukman Fahdiyat ${ }^{1)}$, Zulaikha Putri \\ Pertiwi $^{1)}$ \\ ${ }^{1)}$ Civil Engineering Department of Semarang State Polythecnic \\ Jl. Prof. H. Soedarto, S.H., Tembalang, Semarang 50275 \\ ${ }^{*}$ Email: edymaryamah@gmail.com
}

\begin{abstract}
Darul Hikmah Mosque is a building located inside Politeknik Negeri Semarang as a place of worship for all campus residents, and people who live around the area. The prayer activity is preceded by the Wudu. In order for Wudu to be carried out perfectly, sufficient quantities of water are needed. The lack of pressure and discharge of Wudu tap water, when used simultaneously, becomes a constraint that is the water pressure decreases. The purpose of this study is to determine the factors causing the lack of water discharge or pressure as required in SNI 03-7065-2005. The research method is quantitative descriptive by evaluating the performance of the existing water supply system and using a discrepancy model by comparing the evaluation results with existing data to find discrepancies. Evaluation results indicate that the factors that cause the lack of water pressure are the roof tank height is less than ideal for water distribution with gravitational power, and the volume of available water is not sufficient
\end{abstract}

Keywords : clean water supply, clean water requirements, reduced pressure, water Discharge

\section{INTRODUCTION}

Darul Hikmah Mosque is a building located in Politeknik Negeri Semarang which is a place of worship for students, lecturers and all campus residents, including local residents who live around the area. The mosque is a place for all Politeknik Negeri Semarang Islamic activities to be held, including five daily prayers (Mahmudi et al, 2018). The prayer activities are preceded by the activities of Wudu. In order for the Wudu to be carried out perfectly, conditions needed to support Wudu activities include a sufficient amount of water, pressure, minimal splashes, and a non-spreading faucets tap. (Widiyanto \& Purnomo, 2014).

In a water distribution system, the flow available in a distribution network depends on the pressure of the distribution network itself. When water pressure in the distribution network is lacking, not all consumer demands will be sufficient (Siew \& Tanyimboh, 2011). The lack of water pressure / Wudu faucets, when used simultaneously during prayer, especially on Friday prayers, is a constraint that occurs in the clean water supply system of the Darul Hikmah Mosque, Politeknik Negeri 
Semarang. Until now there has been no improvement regarding this system because the cause of the lack of emission/pressure from the tap water is unknown.

Some researchers have conducted studies and evaluations of water supply systems that are experiencing problems. Previously (Romadhon \& Syakir, 2014) redesigned the plumbing system in Star Hotel Semarang building to overcome the lack of water pressure on floors 25 , 26, and 27 and excessive pressure on the first floor of the hotel building which caused pipe leaks. The results of the study indicate the need for pipe replacement on the 1 st floor so that the water pressure is normal and adding a booster pump so that the flow of water on the 25th, 26th, and 27th floors can be fulfilled.

From previous studies, it can be seen that most evaluations are carried out on hotel buildings, not yet conducted evaluations of clean water systems for religious buildings, especially mosques. There is required one faucet for every 50 worshipers. For more than 500 worshipers, one faucet must be added for every increase of 200 people.

(Widiyanto \& Purnomo, 2014) stated the speed of the jet of water that comes out of the tap is influenced by the height of the power. In this case, the height of power is the difference in elevation between the water level in a Roof tank and the faucet hole. The higher the power, the greater the emission of water emitting from the faucet. The lack of tap water velocity is affected by the lack of water power flowing from the roof tank. To review the state of the clean water system forWuduactivities can be started from the power equation where ordinary moving liquids are expressed with the Bernoulli equation (Widiyanto \& Purnomo, 2014).

The final evaluation of the clean water supply system at the Darul Hikmah Mosque building in Politeknik Negeri Semarang is intended to find out the causes of the existing problems and solutions to overcome the problem. The results of the evaluation are expected to be a reference to fix the problems of the water supply system.

The main factor to do this evaluation is the lack of tap water for Wudu activities during peak hours use, namely prayer hours and the cause of this problem is unknown. The evaluation constellations of clean water supply systems that have been conducted, no one has done an evaluation for this mosque building. Evaluation by previous researchers carried out on hotel buildings.

The general purpose of the evaluation is to obtain a solution to get the Wudu activities according to the standard during peak hours and understand the cause of lacking tap water amounts. The specific purpose of this study is to conduct a research evaluation of clean water supply systems for mosque buildings. This research is expected to be a guideline for the campus or mosque management to overcome the problems that occur. 


\section{RESEARCH METHOD}

Research methods or procedures are arranged to prove the truth of the framework of thought that has been formed. The method used in evaluating consists of several stages, namely: (a) data collection stage, where the data used are primary data obtained through field surveys and secondary data obtained from books, SNIs, and guidelines and other standards; (b) evaluation of the existing system, which consists of calculating the need for water and water usage during peak hours, calculating the height of the roof tank in order to meet the required pressure, and calculating the capacity of the pump used, analysis of the comparison between height value of the calculated roof tank with height measurement roof tank on the field, as well as concluding the evaluation results; (c) making recommendations for maintenance and maintenance models that are adapted to field conditions. Existing evaluations are carried out using a number of equations by (Noerbambang \& Morimura, 1991) which can be reviewed as follows:

\section{Average Clean Water Usage}

\section{Calculation}

a. Calculate the estimated number of occupants:

$\mathrm{ODE}=\mathrm{EFA} \times \frac{\mathrm{FA}}{\mathrm{OD}}$

Where:

$$
\begin{aligned}
& \text { ODE }=\text { Occupancy density } \\
& \text { estimate } \\
& \begin{aligned}
\text { EFA } & =\text { Effective floor area } \\
& =55 \%-80 \%
\end{aligned}
\end{aligned}
$$

FA $=$ Floor area

OD = Occupancy density $=5$ -

$10 \mathrm{~m}^{2}$

b. Average water usage per day $(\mathrm{Qd})$ :

$\mathrm{Qd}=$ Number of occupants $\times$ water usage

Where:

Average water use per day (worship building) $=10$ liters / person / day

With the addition due to $20 \%$ leakage, so:

$\mathrm{Qd}=1.2 \times \mathrm{Qd}$

Where:

$100 \%+20 \%=120 \%=1.2$

c. Average water usage per hour:

$\mathrm{Qh}=\frac{\mathrm{Qd}}{\mathrm{T}}$

Where:

$\mathrm{Qh}=$ Average water usage $(\mathrm{m} 3 /$ hour)

Period of usage per hour $(\mathrm{T})=2$ hours / person / day (worship building)

d. Water usage during peak hour:

$\mathrm{Q}_{\mathrm{h} \_\max }=(C 1)(Q h)$

with:

$\mathrm{C} 1$ values range between 1.5 to 2.0 .

e. Water usage during peak minute:

$\mathrm{Q}_{\mathrm{m}_{-} \max }=(C 2)\left(\frac{Q h}{60}\right)$

with:

C2 values range between $3.0-4.0$

f. Service pipeline capacity:

$Q s=2 / 3 \times Q h$

with:

Qs = service flow capacity $(\mathrm{m} 3 /$ hour)

g. Ground Water Tank (GWT) capacity and dimension:

$V_{R}=Q d-Q s \times t$ 
with:

$\mathrm{V}_{\mathrm{R}}=$ Volume of the bottom water tank (m3).

$\mathrm{Qd}=$ Number of water requirements per day $(\mathrm{m} 3 /$ day).

Qs = Service pipe capacity (m3/ hour).

$\mathrm{t}=$ Average usage per day (hour / day).

h. Roof tank capacity and dimension:

$$
V_{E}=\left(Q_{p}-Q_{\max }\right) \times T_{p}-Q_{p n} \times T_{p n}
$$

with:

$\mathrm{V}_{\mathrm{E}}=$ Volume of the bottom water tank (m3).

$\mathrm{Q}_{\mathrm{p}}=$ peak demand (liters / minute)

$\mathrm{Q}_{\max }=$ Need for peak hours (liters/minute)

$\mathrm{Q}_{\mathrm{pn}}=$ Filling pump capacity (liters / minute)

$\mathrm{T}_{\mathrm{p}} \quad=$ Period of peak need (minutes)

$\mathrm{T}_{\mathrm{pn}}=$ Work period of fill pump (minutes)

\section{Pressure Calculation}

a. Calculate the water pressure for each floor in order to find out whether the water pressure coming out through the plumbing device on each floor is still within the planning pressure limit for high rise buildings using the formula:

$\rho_{\text {air }}=\mathrm{g} \times \mathrm{H}$

where:

$\mathrm{H}$ (static head) = The height of the floor from the roof

$\rho_{\text {water }}$

$$
=1000 \mathrm{~kg} / \mathrm{m}^{3}
$$

b. Because the above formula produces units of $\mathrm{N} / \mathrm{m}^{2}$, then to adjust the plumbing unit that uses $\mathrm{kg} / \mathrm{cm}^{2}$, it is changed to
$1 \mathrm{~N} / \mathrm{m}^{2}=0.00001 \mathrm{bar}$

$1 \mathrm{bar}=1.0197 \mathrm{~kg} / \mathrm{cm}^{2}$

\section{Head Loss Calculation}

a. Determine the flow rate value of the plumbing unit load

b. Calculate pipe flow velocity

c. Determining the value of $\varepsilon / D$ with $\varepsilon$ is the relative roughness of the material

d. Determine the Reynold number of water flow in the pipe using the formula

$R_{e}=\frac{V \cdot d}{v}$

where:

$\operatorname{Re}=$ Reynold number

$\mathrm{V}=$ fluid flow velocity $(\mathrm{m} / \mathrm{s})$

$\mathrm{D}=$ pipe diameter $(\mathrm{m})$

$\mathrm{v}=$ kinematic viscosity

$=0.984 \times 10-6 \mathrm{~m}^{2} / \mathrm{s}$ for $\mathrm{a}$ temperature of $21.1^{\circ} \mathrm{C}$

e. By using a moody diagram, the magnitude of the coefficient of friction value is obtained $\mathrm{f}$.

f. Calculate straight pipe losses using the formula:

$H_{f}=f \cdot \frac{L}{D} \cdot \frac{v^{2}}{2 g}$

Where:

$\mathrm{Hf}=$ Head loss due to friction $(\mathrm{m})$

$f=$ Friction factor (obtained from Moody's diagram)

$\mathrm{L}$ = pipe length $(\mathrm{m})$

$\mathrm{D}=$ Diameter in the pipe $(\mathrm{m})$

$\mathrm{V}=$ velocity of fluid flow in the pipe $(\mathrm{m} / \mathrm{s})$

$\mathrm{g}=$ gravity

g. Determine pipe equipment used in buildings such as pipe joints, elbows, and valves

h. Find the equivalent length of the pipe equipment in the building, 
using the equivalent pipe length table

i. Calculate the loss of pipe equipment with the formula:

$H_{f}=f \cdot \frac{v^{2}}{2 g}$

Where:

$\mathrm{H}_{\mathrm{f}}=$ Head loss due to friction (m)

$f=$ Friction factor (obtained from Moody's diagram)

$$
\begin{aligned}
\mathrm{V}= & \text { velocity of fluid flow in the } \\
& \text { pipe }(\mathrm{m} / \mathrm{s}) \\
\mathrm{g}= & \text { gravity }
\end{aligned}
$$

4. Calculation of Pump Head and Pump Power

The calculation of head and pump power is determined by a graph of the relationship between total Head Loss and the flow rate obtained.

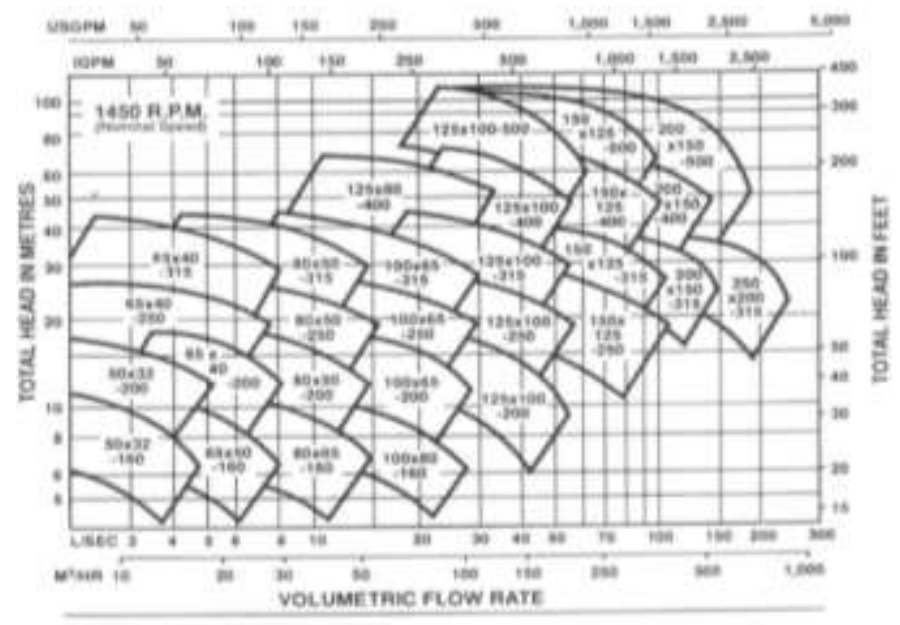

Figure 1. GRUNDFOS Pump Types

(Source: Noerbambang \& Morimura, 2005)

5. Calculation of Tank Top Height

The critical head loss calculation is used to determine the height of the upper tank. Critical head loss is calculated based on the longest path or the highest number of plumbing tools, thus producing the largest head loss. Here are the equations for calculating the critical head loss and top tank height.

$$
\begin{aligned}
\mathrm{H}_{\mathrm{av} \_ \text {tank }} & =\mathrm{H}_{\mathrm{av} \_ \text {floor }}-\left(\mathrm{H}_{\mathrm{L} \_ \text {critical }}+\right. \\
& \mathrm{H}_{\mathrm{L} \_ \text {pipe }} \text { from the tank }+ \\
& \mathrm{H}_{\mathrm{L} \_ \text {upright pipe }}+\mathrm{P}_{\text {plumbing }} \\
& \text { units })
\end{aligned}
$$

Information:
$\mathrm{H}_{\mathrm{av}} \quad=$ Head available

$\mathrm{H}_{\mathrm{L}_{\text {c critical }}}=$ Critical headloss

$\mathrm{H}_{\mathrm{av} \_ \text {floor }}=\mathrm{is}$ the elevation difference between the highest floor and the lowest plumbing tool

Or you can also use the formula:

$h=\frac{P}{\rho \cdot g}+H_{L_{-} \text {critical }}$

Information:

$\rho=$ Density of water $=1000 \mathrm{~kg}$ $/ \mathrm{m}^{3}$

$\mathrm{g}=$ Gravity $\quad=9.8 \mathrm{~m} /$ $\mathrm{s}^{2}$

$\mathrm{h}=$ Height of roof tankplumbing tool 


$$
\begin{aligned}
& \mathrm{P}=\text { Pressure }=0.3 \mathrm{~kg} / \\
& \mathrm{cm}^{2} \\
& \mathrm{H}_{\text {av_floor }}=\text { is the elevation } \\
& \text { difference between the } \\
& \text { highest floor and the } \\
& \text { lowest plumbing tool }
\end{aligned}
$$

\section{Preparation of Maintenance Methods}

Maintenance models are based on conditions in the field. With this model, a good and correct maintenance system will be known in accordance with the existing SNI. Maintenance models that will be made are tested to experts, in this case, are mosque technicians (caretakers) in the form of questionnaires along with compiled SOPs.

\section{RESULTS AND DISCUSSIONS}

The results and discussion of this research are water requirements based on the number of users (users), water requirements based on the plumbing unit, type of pump used, roof tank capacity, pipe diameter should be, speed and pressure flow that must be met, type of maintenance and maintenance, and maintenance checklist and maintenance. Calculated based on the floor area of the building and the highest number of users at one time of prayer, the number of worshipers was 539 people. From the number of worshipers obtained the following results:

$$
\begin{aligned}
\text { Occupancy density estimate } & =\text { Effective floor area } \times \frac{\text { Floor area }}{\text { Occupancy density }} \\
& =70 \% \times\{[(21.75 \times 21.05)+(21.73 \times 7.2)] / 0.88\} \times 1.1 \\
& =539 \text { people }
\end{aligned}
$$

$\mathrm{Q}_{\mathrm{d}} \quad=$ Number of occupant's $\times$ water use $\quad=(539 \times 10 \times 1.2) / 1000=6.468$ $\mathrm{m}^{3} /$ day

$$
\begin{array}{llll}
\mathrm{Q}_{\mathrm{h}} & =\mathrm{Qd} / \mathrm{T} & =6,468 / 2 \text { hours } & =3,234 \mathrm{~m}^{3} / \text { hour } \\
\mathrm{Q}_{\mathrm{h} \max }=(\mathrm{C} 1)(\mathrm{Qh}) & =1.5 \times 3.234 & =4,850 \mathrm{~m}^{3} / \text { hour } \\
\mathrm{Q}_{\mathrm{m} \max }=(\mathrm{C} 2)(\mathrm{Qh}) / 60 & =3 \times 3.234 / 60 & =0.162 \mathrm{~m}^{3} / \text { minute }
\end{array}
$$

Table 1. Average Water Usage Based on Number of Residents

\begin{tabular}{ccccc}
\hline $\begin{array}{c}\text { Number of Users } \\
\text { (Person) }\end{array}$ & $\begin{array}{c}\text { Qh } \\
\mathrm{m}^{3} / \text { hour }\end{array}$ & $\begin{array}{c}\text { Qh-max } \\
\mathrm{m}^{3} / \text { hour }\end{array}$ & $\begin{array}{c}\text { Qm-max } \\
\mathrm{m}^{3} / \text { minute }\end{array}$ \\
\hline 539 & 6,468 & 3,234 & 4,850 & 0,162 \\
\hline
\end{tabular}

Source: 2019 Site Research Results

To calculate the diameter of the pipe in the building whether it needs to be enlarged or not, it is necessary to calculate the flow rate using a flow velocity chart based on the plumbing unit load. From the calculations according to the formula above, the following recommendations in Table 3 are obtained: 
Table 2. Flow Rate Based on Plumbing Unit

\begin{tabular}{ccccc}
\hline Location & $\begin{array}{c}\mathrm{N} \\
\text { Faucet }\end{array}$ & $\begin{array}{c}\text { Unit loading } \\
\text { number }\end{array}$ & Load & $\begin{array}{c}\text { Velocity } \\
\text { (Liter/ sec) }\end{array}$ \\
\hline Women faucets (inside) & 10 & & 20 & 0,48 \\
Women faucets (outside) & 5 & 2 & 10 & 0,35 \\
Men faucets I & 14 & & 28 & 0,57 \\
Men faucets II & 8 & & 16 & 0,4 \\
\hline & Total & & & 1,80 \\
\hline
\end{tabular}

Source: 2019 Site Research Results

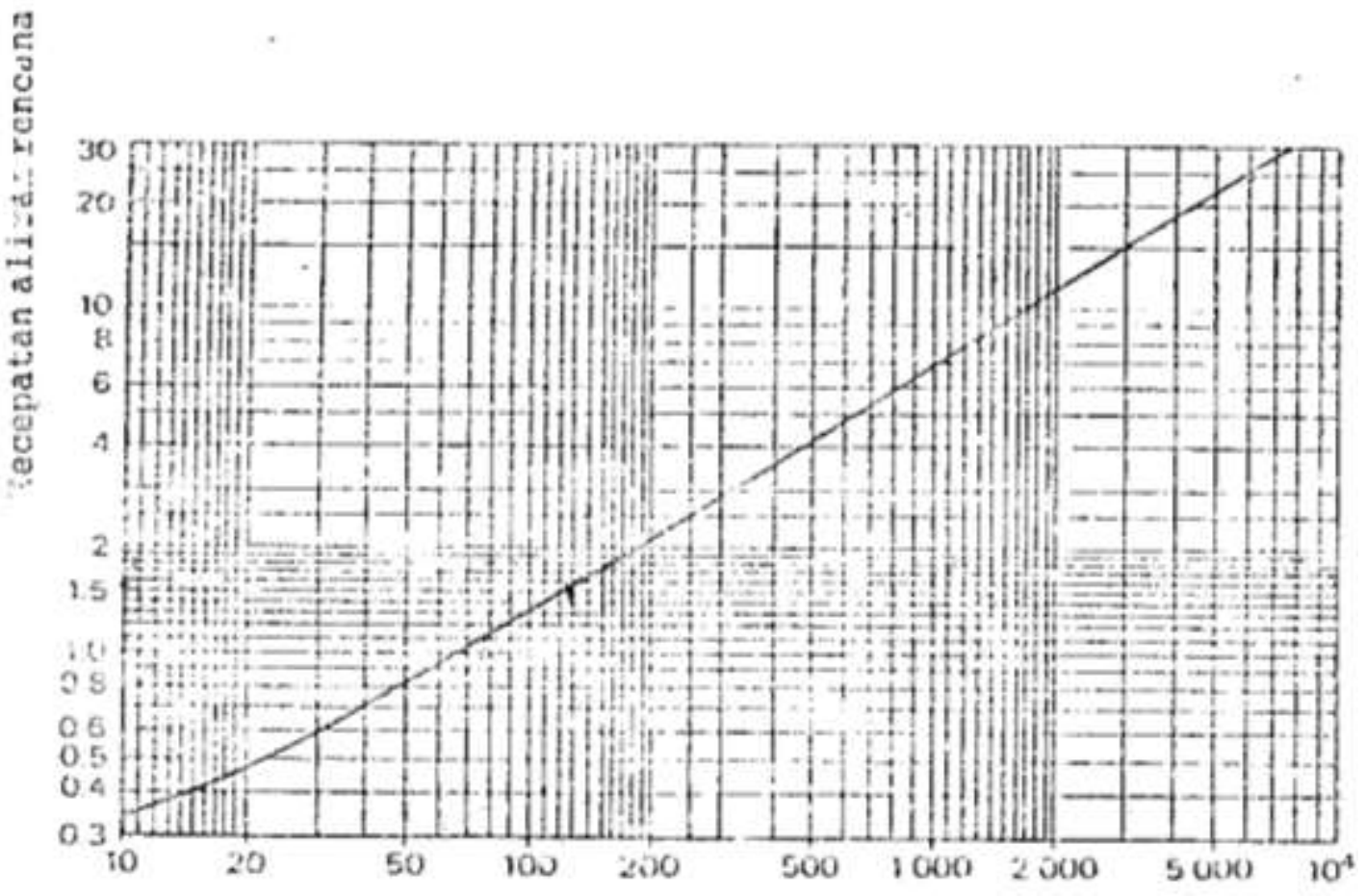

Graph 1. Flow Rate (Liter/sec)

(Source: Noerbambang \& Morimura, 2005)

Table 3. Final Results of Pipeline Calculations

\begin{tabular}{|c|c|c|c|c|c|c|c|}
\hline $\begin{array}{l}\text { Pipe } \\
\text { Number }\end{array}$ & $\begin{array}{l}\text { Velocity } \\
\text { (liter / } \\
\text { sec) }\end{array}$ & $\begin{array}{c}\mathrm{D} \\
(\mathrm{m})\end{array}$ & $\begin{array}{l}\text { Head } \\
\text { loss } \\
(\mathrm{m})\end{array}$ & $\begin{array}{l}\text { Height } \\
\text { Used } \\
(\mathrm{m})\end{array}$ & $\begin{array}{c}\text { Total } \\
\text { Height } \\
\text { Used } \\
(\mathrm{m}) \\
\end{array}$ & $\begin{array}{c}\text { Actual } \\
\text { Height } \\
\text { (m) }\end{array}$ & Recommendation \\
\hline $1-3$ & 1,35 & 0,0254 & 0,26 & 2,860 & 4,212 & 5,5 & $\begin{array}{l}\text { Use the original } \\
\text { diameter }\end{array}$ \\
\hline $4-15$ & 1,35 & 0,0254 & 0,26 & 5,187 & 31,762 & 5,5 & Increase in diameter \\
\hline $16-23$ & 0,48 & 0,01905 & 0,19 & 0,606 & 2,442 & 2,5 & $\begin{array}{l}\text { Use the original } \\
\text { diameter }\end{array}$ \\
\hline $24-25$ & 0,42 & 0,01905 & 0,16 & 0,328 & 5,810 & 2,5 & Increase in diameter \\
\hline $26-32$ & 0,35 & 0,01905 & 0,11 & 0,317 & 2,800 & 3,0 & $\begin{array}{l}\text { Use the original } \\
\text { diameter }\end{array}$ \\
\hline $33-59$ & 0,35 & 0,01905 & 0,11 & 0,286 & 45,942 & 3,0 & Increase in diameter \\
\hline $60-64$ & 0,5 & 0,01905 & 0,21 & 0,242 & 2,856 & 3,0 & $\begin{array}{l}\text { Use the original } \\
\text { diameter }\end{array}$ \\
\hline
\end{tabular}




\begin{tabular}{cccccccl}
\hline $65-75$ & 0,5 & 0,01905 & 0,21 & 0,483 & 13,489 & 3,0 & Increase in diameter \\
$76-79$ & 0,40 & 0,01905 & 0,14 & 0,231 & 1,876 & 3,0 & Use the original \\
diameter \\
$80-86$ & 0,40 & 0,01905 & 0,14 & 1,708 & 5,820 & 3,0 & Increase in diameter \\
\hline
\end{tabular}

Source: 2019 Site Research Results

To determine the pump power that must be used, it is necessary to first acknowledge the head loss $\left(\mathrm{h}_{\mathrm{f}}\right)$ friction loss by involving the length of the pipe and all the connections that exist.

Table 4. Head Loss Usage

\begin{tabular}{|c|c|c|c|c|c|c|c|c|c|c|}
\hline \multirow[b]{2}{*}{$\begin{array}{l}\text { Pipe } \\
\text { Num. }\end{array}$} & \multirow[b]{2}{*}{$\operatorname{Re}$} & \multirow[b]{2}{*}{$\mathrm{f}$} & \multirow[b]{2}{*}{$\begin{array}{c}\mathrm{L} \\
(\mathrm{m})\end{array}$} & \multirow{2}{*}{$\begin{array}{c}\text { Straight } \\
\text { Pipe } \\
\left(\mathrm{H}_{\text {mayor }}\right) \\
(\mathrm{m})\end{array}$} & \multicolumn{4}{|c|}{ Pipe Tools $\left(\mathrm{H}_{\text {minor }}\right)$} & \multirow[b]{2}{*}{$\begin{array}{l}\mathrm{hf} \\
(\mathrm{m})\end{array}$} & \multirow[b]{2}{*}{$\begin{array}{c}\mathrm{hf} \\
\text { Usage } \\
(\mathrm{m})\end{array}$} \\
\hline & & & & & $\begin{array}{c}\text { Elbow } \\
\text { (m) }\end{array}$ & $\mathrm{T}(\mathrm{m})$ & $\begin{array}{c}\text { Gate } \\
\text { Valve } \\
(\mathrm{m})\end{array}$ & $\begin{array}{c}\text { Ball } \\
\text { Valve } \\
(\mathrm{m})\end{array}$ & & \\
\hline $1-15$ & 600,01 & 0,02 & 107,16 & 10,072 & 1,676 & - & - & - & 11,748 & 11,748 \\
\hline $16-18$ & 27389,25 & 0,017 & 2,900 & 0,257 & 0,073 & 0,122 & 0,016 & - & 0,469 & \\
\hline $19-20$ & 3994,26 & 0,040 & 1,475 & 0,005 & 0,002 & 0,003 & - & - & 0,009 & 2046 \\
\hline $21-22$ & 3994,26 & 0,040 & 3,150 & 0,010 & 0,002 & 0,003 & - & - & 0,014 & $2,0+0$ \\
\hline $23-25$ & 23965,59 & 0,025 & 8,500 & 0,602 & 0,112 & 0,841 & - & - & 1,555 & \\
\hline $26-38$ & 19971,33 & 0,026 & 35,050 & 1,792 & 0,311 & 0,389 & 0,009 & - & 2,501 & 2,501 \\
\hline $45-59$ & 52068,10 & 0,021 & 59,420 & 8,117 & 1,529 & 0,000 & 0,026 & - & 9,672 & 9,672 \\
\hline $60-72$ & 33665,95 & 0,024 & 20,027 & 2,573 & 1,327 & 2,212 & - & 0,025 & 6,138 & \\
\hline $73-74$ & 3994,26 & 0,040 & 5,470 & 0,017 & 0,000 & 0,005 & - & - & 0,022 & 6,183 \\
\hline 74- 75 & 3994,26 & 0,040 & 5,470 & 0,017 & 0,002 & 0,005 & - & - & 0,024 & \\
\hline $76-83$ & 22824,37 & 0,018 & 17,187 & 1,216 & 0,392 & 0,000 & - & 0,012 & 1,621 & \\
\hline $84-85$ & 7988,53 & 0,033 & 4,690 & 0,049 & 0,031 & 0,021 & - & - & 0,101 & 1,822 \\
\hline $84-86$ & 7988,53 & 0,033 & 4,690 & 0,049 & 0,031 & 0,021 & - & - & 0,101 & \\
\hline
\end{tabular}

Source: 2019 Site Research Results

Based on the head loss / total friction loss and flow (Liter/sec), then plotted as in the GRUNDFOS pump graph
(Figure 2) the following results are obtained:

( ......) Well pump

$$
\begin{aligned}
& \mathrm{H}_{\text {mayor }}=10,072 \mathrm{~m} \quad \mathrm{H}_{\text {minor }}=1,676 \mathrm{~m} \\
& \mathrm{H}_{\text {static }}=30,6 \mathrm{~m} \quad \mathrm{H}_{\text {energy }}=0,143 \mathrm{~m} \\
& \mathrm{H}_{\text {Total }}=\mathrm{H}_{\text {mayor }}+\mathrm{H}_{\text {minor }}+\mathrm{H}_{\text {static }}+\mathrm{H}_{\text {energy }}=42,491 \mathrm{~m} \\
& \mathrm{Q}_{\mathrm{d}}=0,913 \mathrm{~m}^{3} / \mathrm{sec}
\end{aligned}
$$


( -) Roof tank pump

$$
\begin{aligned}
& \mathrm{H}_{\text {mayor }}=8,80 \mathrm{~m} \quad \mathrm{H}_{\text {minor }}=2,098 \mathrm{~m} \\
& \mathrm{H}_{\text {static }}=1,6 \mathrm{~m} \quad \mathrm{H}_{\text {energy }}=0,176 \mathrm{~m} \\
& \mathrm{H}_{\text {Total }}=\mathrm{H}_{\text {mayor }}+\mathrm{H}_{\text {minor }}+\mathrm{H}_{\text {static }}+\mathrm{H}_{\text {energy }}=12,674 \mathrm{~m} \\
& \mathrm{Q}_{\mathrm{d}}=1,348 \mathrm{~m}^{3} / \mathrm{sec}
\end{aligned}
$$

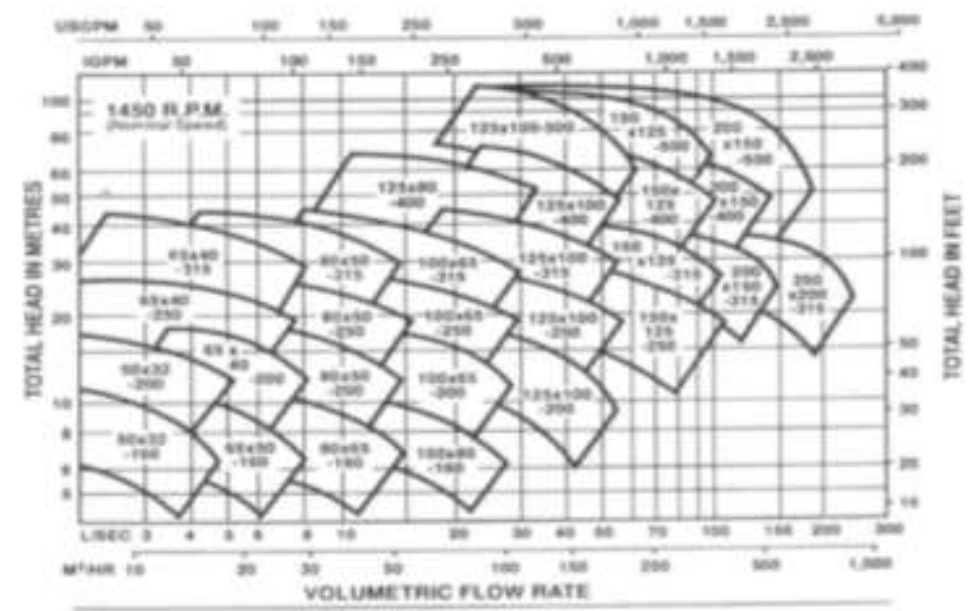

Figure 2. GRUNDFOS Pump Types

(Source: Noerbambang\& Morimura, 2005)

Table 5. Pump Types

\begin{tabular}{ccccccccc}
\hline Pump Location & $\begin{array}{c}\mathrm{Hf}_{\text {mayor }} \\
(\mathrm{m})\end{array}$ & $\begin{array}{c}\mathrm{Hf}_{\text {minor }} \\
(\mathrm{m})\end{array}$ & $\begin{array}{c}\mathrm{H}_{\text {statis }} \\
(\mathrm{m})\end{array}$ & $\begin{array}{c}\mathrm{H}_{\text {energi }}(\mathrm{m}) \\
(\mathrm{m})\end{array}$ & $\begin{array}{c}\mathrm{H}_{\text {total }} \\
(\mathrm{mm})\end{array}$ & $\begin{array}{c}\text { Suction } \\
\text { Pump Dia. } \\
(\mathrm{mm})\end{array}$ & $\begin{array}{c}\text { Thrust } \\
\text { Pump Dia. }\end{array}$ & $\begin{array}{c}\text { Electrical } \\
\text { Power } \\
(\text { watt })\end{array}$ \\
\hline Men's Roof Tank & 8,117 & 1,555 & 1,6 & 0,131 & 11,403 & 50 & 32 & 200 \\
Well & 10,072 & 1,676 & 30,6 & 0,143 & 42,491 & 65 & 40 & 315 \\
\hline
\end{tabular}

Source: 2019 Site Research Results

From the calculation of the average occupants, it is also used to calculate water usage based on the number of the dimensions of the roof tank by:

$$
\begin{aligned}
\mathrm{V}_{\mathrm{E} \_ \text {man }} & =\left[\left(\mathrm{Q}_{\mathrm{p}}-\mathrm{Q}_{\mathrm{h} \max }\right) \times \mathrm{T}_{\mathrm{p}}\right]-\left[\mathrm{Q}_{\mathrm{pu}} \times \mathrm{T}_{\mathrm{pu}}\right] \\
& =[(110-54,75) \times 60]-[54,75 \times 30] \\
& =1672,5 \text { Liter }=1,672 \mathrm{~m}^{3} \\
\mathrm{~V}_{\mathrm{E} \_ \text {woman }} & =\left[\left(\mathrm{Q}_{\mathrm{p}}-\mathrm{Q}_{\mathrm{h} \max }\right) \times \mathrm{T}_{\mathrm{p}}\right]-\left[\mathrm{Q}_{\mathrm{pu}} \times \mathrm{T}_{\mathrm{pu}}\right] \\
& =[(162-80,85) \times 60]-[80,85 \times 30] \\
& =2443,5 \text { Liter }=2,443 \mathrm{~m}^{3}
\end{aligned}
$$

The volume of the roof tank that has been calculated is then adjusted to the size on the market. Roof tank size used is $\geq \mathrm{VE}$. 
Table 6. Roof Tank Dimension

\begin{tabular}{|c|c|c|c|c|c|c|}
\hline \multirow[b]{2}{*}{$\begin{array}{c}\text { Roof Tank } \\
\text { Position }\end{array}$} & \multirow{2}{*}{$\begin{array}{l}\text { Site Roof } \\
\text { Tank } \\
\text { Capacity } \\
\text { (liter) }\end{array}$} & \multirow[b]{2}{*}{$\begin{array}{c}\text { Roof Tank } \\
\text { Volume } \\
\text { (liter) }\end{array}$} & \multirow{2}{*}{$\begin{array}{c}\text { Available } \\
\text { Roof Tank } \\
\text { Capacity } \\
\text { (liter) }\end{array}$} & \multicolumn{3}{|c|}{ Roof Tank Dimension on The Market } \\
\hline & & & & $\begin{array}{l}\text { Lid Dia. } \\
\quad(\mathrm{m})\end{array}$ & $\begin{array}{c}\text { Roof Tank } \\
\text { Dia.(m) }\end{array}$ & $\begin{array}{c}\text { Roof Tank } \\
\text { Height } \\
\text { (m) }\end{array}$ \\
\hline Men & 520 & 1672,5 & 2000 & 6,00 & 1,44 & 1,485 \\
\hline Woman & 2000 & 2443,5 & 3100 & 6,00 & 1,44 & 2,120 \\
\hline
\end{tabular}

Source: 2019 Site Research Results

In order to meet the standard pressure of $1 \mathrm{~kg} / \mathrm{cm}^{2}$ it is necessary to calculate the height of the roof tank

$$
h=\frac{p}{\rho \times g}+H_{L \text { critical }}=\frac{0.3}{1000 \times 9.8 \times 0.0001019}+10.898=10.898 \text { meter }
$$

To minimize the damage in the site, maintenance and care need to be done on all components as follows:

\section{Piping System}

a. PVC pipes that are not protected from the sun's heat require observation.

b. Add a hanger as support for PVC pipes if there is a loose hanger.

c. If there is a leak in the PVC pipe connection, then: Turn off the water flow from the faucet. Glue back with a similar PVC glue or bandage with old rubber tires in the motor in case of emergency (temporary).Re-run the water flow.

d. Hanger or pipe support must be in accordance with the location and position of the pipe, pipe material, as well as the distance between them so that the pipe is not stuck when it expands or shrinks.

\section{Water Faucet System}

a. Check at least every 2 (two) months for each faucet.

b. Tighten the bolt fastening around the faucet. c. Replace if necessary, seal/rubber on the tap rod swivel.

d. If there is a leak in the faucet, stop the water supply in the area by turning the stop-valve.

\section{Ground Water Tank and Roof} Tank System

a. Check the alarm when the water reaches the upper limit.

b. Check the alarm when the water reaches the lower limit.

c. Check water quality.

d. Tank walls should not experience cracks or leaks.

e. The area around the tank must be clean, healthy, and maintained so that no impurities can enter the tank.

f. When periodic inspections are conducted, the tank lid must be opened and seen if there is rust, dirt or other foreign objects floating in the water, deposits, oil layers on the water surface, insects, or plants.

g. Cleaning the tank and disinfection needs to be done twice in a row. After washing the tank with water, before disinfection, used washing 
water must be completely discharged and all parts of the tank dried with a clean cloth.

h. The height of the water level in the tank needs to be maintained, it can be by using a ball-valve with a float, an electrically driven valve, an estimating electrode and so on.

i. Electrical components that are part of the water level indication system, such as switches and relays, must be checked periodically to ensure that the entire system is always working properly.

j. Check the residual levels of chlorine and the quality of water that comes out of the tap (0.2 ppm or more), if the tank cleaning and disinfection process is complete and has been filled with new water.

k. An examination of possible leaks needs to be done periodically, to prevent the emergence of unwanted things. Most leaks occur in parts of the pipe joints and equipment. Periodic inspections can give an early indication of a possible leak so that maintenance or prevention can be taken.

\section{Pump System}

a. Check the water pump status.

b. Check the clean water pump alarm trip.

c. The pump is started every 1 hour before entering prayer time.

d. The suction pressure and thurst pressure of the pump need to be checked every day to find out whether the pump is working normally. e. The available electric voltage must match what is demanded by the electric motor driving the pump. Checking the mains voltage regularly is necessary to prevent the motor from burning due to the voltage passing through the limits allowed for the motor.

f. Observations and checks need to be made when the pump is working, whether there is noise or unnatural movements.

\section{CONCLUSIONS}

From the analysis and evaluation of clean water supply systems in mosque building that use gravity in the distribution of water, some conclusions can be obtained that based on the prayer area, the effective area used, and the area per person, 539 people were obtained as the total number of mosque users. The dimensions of the pipes in the field 1" and 3/4" are not appropriate so they must be enlarged to $1 \frac{1 / 4}{4}$ and $1 "$.

The type of roof tank pump used is a pump with a suction pipe diameter of $50 \mathrm{~mm}$, a thrust pipe diameter of the $32 \mathrm{~mm}$ with a power of 200 watts. The type of well pump used is a pump with a suction pipe diameter of $65 \mathrm{~mm}$, a thrust pipe diameter of 40 mm with a power of 315 watts.

Roof tank capacity in the site does not match the roof tank volume based on water needs, so it must be replaced with a larger capacity, which is 2000 liters for men'sroof tank and 3100 liters for woman'sroof tank after adjusted to the capacity of roof tank available on the market. To get the 
faucet pressure according to the standard that is equal to $0.3 \mathrm{Kg} / \mathrm{cm}^{2}$, then the height obtained from the roof tank up to the plumbing tool is 10.898 meters. The maintenance and care that has been arranged are expected to be applied to the clean water supply system in the mosque building to minimize the occurrence of damage or unwanted problems that might occur later on.

\section{ACKNOWLEDGEMENTS}

The author thanks the Department of Civil Engineering in Politeknik Negeri Semarang for helping and supporting this research so that it can be carried out smoothly.

\section{REFERENCES}

Araujo, L.S., Ramos, H., Coelho, S.T., 2006, Pressure Control for Leakage Minimization in Water Distribution Systems Management. Water Resources Management, Page 133-149.

Artaya, K.C.B., dan Atmaja, G.I., 2010, Perencanaan Instalasi Air Bersih dan Air Kotor Pada Bangunan Gedung dengan Menggunakan Sistem Pompa. Jurnal Ilmiah Teknik Mesin.Vol. 4, No. 1, Page 5156.

Ingeduld, P., Pradhan, A., Svitak, Z., \& Terrai, A., 2006, Modeling Intermittent Water Supply Systems with Epanet. USA, Page 1-7.

Liong, S.Y., dan Atiquzzaman, Md., 2004, Optimal Design of Water
Distribution Network Using Shuffled Complex Evolution. Singapore: Journal of The Institution of Engineers. Vol. 44, Page 93-107.

Markova, J., dan Harbul'akova, V.O., 2016, Monitoring of water quality of selected wells in Brno district. Journal of Civil Engineering. Vol. 11, Page 3140.

Siew, C., dan Tanyimboh, T.T., 2012, Pressure-Dependent EPANET Extension. Water Resour Manage, Page 1477-1498.

SNI 03-7065-2005. Tata Cara Perencanaan Sistem Plumbing. Jakarta: Badan Standarisasi Nasional, 2005.

SNI 03-6481-2000. Sistem Plumbing.

Jakarta: Badan Standarisasi Nasional, 2000.

Wadowsky, R.M., Yee, R.B., Mezmar, L., Wing, E.J., Dowling, J.N., 1982, Hot Water Systems as Sources of Legionella pneumophila in Hospital and Nonhospital Plumbing Fixtures. Applied and Environmental Microbiology, Page 1104-1110.

Wong, L.T., Mui, K.W., 2006, Modeling Water Consumption and Flow Rates for Flushing Water Systems in High-Rise Residential Buildings in Hong Kong. Hong Kong: The Hong Kong Polytechnic University, Page 2025-2034. 